\title{
The job description and the marketing manager- an aid or a hindrance
}

\author{
Dr R. Abratt \\ Graduate school of Business, University of the Witwatersrand, Johannesburg
}

This paper explores the feasibility of applying a standard job description to the chief of the marketing department of the firm. This implies that the traditional job description theory may not be adequate for describing the job of the marketing manager or conversely, that marketing theory is not applied to job description. This paper discusses some aspects of job descriptions, the task of the marketing manager and then looks at the five actual job descriptions of marketing managers in five major companies in different industries. Conclusions are drawn from these findings.

S.Afr. J. Bus. Mgmt. 1983, 14: $11-18$

Hierdie artikel ondersoek die moontlikheid om 'n standaard. werksbeskrywing toe te pas op die posisie van hoof van die bemarkingsdepartement van 'n organisasie. Dit impliseer dat die tradisionele werksbeskrywingsteorie nie voldoende is om die werk van die bemarkingsbestuurder te beskryf nie, of omgekeerd, dat bemarkingsteorie nie toegepas word vir werksbeskrywing nie. Die skrywer bespreek sekere aspekte van werksbeskrywings, die taak van die bemarkingsbestuurder en ondersoek dan vyf werklike werksbeskrywings van bemarkingsbestuurders in vyf groot maatskappye in verskillende bedryfsektore. Gevolgtrekkings vanuit die bevindinge word bespreek.

S.Air. Tydskr. Bedryfst. 1983, 14: 11-18
Graduate School of Business, University of the Witwatersrand, P.O. Box 31170 , Braamfontein 2017, Republic of South Africa

\section{Objective}

The objective of this paper is to establish whether a standard job description can be applied to the chief of the marketing department in the firm. This means that it is not clear whether traditional job description theory is adequate for the job of marketing manager or conversely marketing theory is not applied to job descriptions. This paper discusses some aspects of job descriptions, the tasks of the marketing manager and then looks at five actual job descriptions of marketing managers in five major companies in different industries. Conclusions are then drawn from the findings.

\section{The job description}

According to Orpen", "the first aim of job analysis is to obtain a description of the nature and scope of the job in question as currently constituted, apart from the persons performing them. It is behaviour-centred in that it defines the job in terms of the actual behaviours necessary for successfully performing it.'

A job description should be an accurate and realistic picture of what is expected of the individual doing the job. It outlines the job's location in the organization, the content and purpose, the relationship involved, authority and controls. It should be a dynamic document changing with the times, the conditions of work and sometimes with the individual performing the job. It must be clearly written and understood. The incumbent and the supervisor must understand it equally well and must interpret it in the same way.

\section{The functions of a job description include ${ }^{2}$}

- A selling document. It can be used to sell the job and the company to a new candidate. Therefore the description should be clear and precise.

- A selection tool and interview guide. It can be used to assist the interviewer in making a more accurate selection of candidates. It can be used as a guide to the interviewer in forming the right job-related questions.

- It can assist the applicant as a self-evaluating checklist to help him gauge his competence to handle any of the work called for in the job description.

- A starting point for the orientation and actual jobtraining. Both for the trainee and the trainer, the job description is a natural beginning point and founda- 
tion for building a training and development programme for the job.

- A basis for defining responsibility and levels of authority. Once job content on key activities of a job have been described, responsibility can be delegated with the appropriate authority to perform the key areas.

- A framework for performance and progress review. The job description provides a guide for the worker and the supervisor in establishing job objectives, standards of performance and assessing performance. Objectives and standards of performance can be set if the contents of the jobs are clearly described and both the incumbent and the supervisor understand the job description, and what is involved in the job.

A well-made job description should be up to date and give an over-view of what the job essentially is. It indicates what the job is, as well as how and to what extent the particular job differs from other jobs.

According to Klinger ${ }^{3}$, there are two other factors that should be included in job descriptions but are often left out. Firstly, it must specify the performance expected of the employee, and secondly clues should be provided concerning the conditions under which the job is to be performed.

Job descriptions will vary according to the type of job being described. We are only concerned with the job description of the marketing manager.

The marketing manager should be a part of the top management team in the firm. If one looks at marketing theory, most writers ${ }^{4}$ state that the undermentioned are six tasks that have to be performed by the marketing manager.

\section{The analysis of marketing opportunities}

The first task of the marketing manager is to determine what opportunities there are in the market for the products of the firm. Environmental conditions play an important role because they influence marketing conditions. Some environmental factors are:

- the strength of the competition

- government laws and actions

- technological developments

- economic and social factors

\section{The Setting up of Goals for Marketing Operations}

Marketing management must have in writing the future goals the firm hopes to achieve with its marketing operations. Goals are arrived at as a result of forecasts made by management. As such they are very important in planning and directing operations. They thus become set standards by which marketing activities are controlled. For example, specific sales objectives must be laid down. The sales objective is determined by looking up past records, the state of the economy, environmental changes and changes in distribution or price.

\section{The Development of an Internal Marketing Organization}

The goals aimed at by the firm's marketing programme affect and are affected by the internal organization of the firm. The goals affect employees and teams of employees in that the jobs they do should be co-ordinated by the best system available. The result of the team effort should be that the products of fered to each market are the best the firm can produce and are promoted by the best promotion programme possible within the budget of the firm.

\section{The Acquisition of the Necessary Resources}

For a marketing programme to operate successfully the marketing department must have certain resources at its disposal. Therefore, as marketing goals have been set, the marketing department must have the resources that it will need to reach these goals. This may require more people, larger premises and more capital.

\section{The Creation of Goods and Services for the Market}

A marketing programme cannot succeed unless products are produced for specific target markets at prices which the customers in those markets can afford. Furthermore, the products must be available at outlets that are conveniently placed for potential customers. Marketing management must therefore decide which products they are going to market and at what prices they are going to sell; how the products are going to be distributed and how the manufacturer is going to communicate the relevant marketing information about the products to everyone in the distribution chain and to the final consumer or user.

This requires the development of a marketing strategy. A strategy consists of two distinct parts which are interrelated. The two parts are first, the selection of suitable target markets for the firm's products, and second, establishing a marketing mix for each product, and for each target market.

The marketing mix consists of four controllable variables namely product, price, place and promotion (the 4 p's). These four controllable variables are used by the marketer to assist him in gaining some form of control over the fifth but uncontrollable variable, the consumer.

\section{The Continuous Evaluation and Control of Marketing Achievement}

At least once a year the organization must take stock of its marketing achievements. Problem areas must be discovered and investigated. A marketing or self-audit must be done and actual performance must be compared to the set goals. This may involve the changing of the set standards.

The end result of successful marketing management should be satisfied consumers, contented workers, and happy shareholders.

It was decided to examine five job descriptions for marketing Directors or Managers to see if:

(a) They conform to what the job description theorists profess to be good job description.

(b) They conform to what marketing theorists profess to be the functions of marketing management.

The five job descriptions chosen come from multinational companies operating in South Africa ${ }^{5}$. Each represented a different industry:

- A Tool Manufacturer

- An Oil Company

- A Paper Products Manufacturer 
A Drug Manufacturer

A Retail Chain Store Group

Each job description is given below.

The tool manufacturer's job description

Job Title: Marketing and Sales Manager

Responsible to: General Manager

Main purpose of job

To meet/exceed the Metalworking Products Division annual sales budget, whilst maintaining the level of Administration and Service Costs within the sales trend, so that the nett operating result can be obtained.

To organize, lead and control, through reporting managers, the field sales and special tools design teams to meet/exceed their respective commitments (related to overall divisional objectives) through sales to direct customers and service support to distributors inside given geographical areas.

To create and maintain a high standard of professionalism for all activities within area of responsibility.

\section{Duties and responsibilities - marketing}

In conjunction with General Manager and Marketing Services Manager, determine the local Marketing Policy, in keeping with that of the company, for the forthcoming year (i.e. sales increase by volume, market share development, Administration and Services Costs, possible price increases, establish results, gross and nett.)

Estimate sales by area and region using knowledge and experience of Sales team. Prepare conclusions and submit to General Manager for analysis.

Meet at least weekly with Special Tools Manager to discuss and analyse present order and quotation development (i.e. pricing, quality, Administration and Service Costs, operating results and required changes in marketing tactics).

Assume responsibility for the Agenda and all activities related to the Annual National Sales Conference, presenting, in written form, the marketing policy and strategy.

Establish and maintain a discount structure, together with Marketing Services Manager and reporting Managers, that allows for volume increases in sales in a competitive market while attaining profitability as set out in the marketing policy.

Appoint authorized distributors in accordance with guidelines. Cancel agreements, when necessary, with ineffective distributors. Prepare sales and product activities through co-ordination of Technical Services, Public Relations and advertising departments with emphasis on the promotion of key and new products.

\section{Duties and responsibilities - sales}

Monitor (monthly with Regional Managers) and review (quarterly with complete Field Sales Team) sales development at customer level, product mix and sales target. Determine necessary marketing tactics and/or other actions for the immediate future (to be evaluated during next review).
Establish and maintain positive relationships with main contacts and key accounts, potential customers and distributors (e.g. regular visits).

Support the effectiveness of the divisional sales operation (e.g. visits to end users and distributors) especially in stress situations and where there is high company commitment in projects/orders.

Draw up quarterly Time Plan (with reporting Managers) bringing activities in line with Marketing Plan and Programme.

Ensure that Regional Managers follow up long-term outstanding accounts in keeping with divisional objectives in this regard. Vet 'Stop Supply List' and determine (together with Reporting Managers), those customers that should be placed on 'Stop Supply' before re-issuing for implementation.

Ensure accurate up-to-date information on all competitors' activities (i.e. strategies, organization, major customers, personnel etc.)

This information documented and filed for reference.

\section{Duties and responsibilities - administration}

Responsible for total autonomy of Administration and Services costs within Marketing and Sales areas.

Estimate Administration and Services Cost Budget for forthcoming year (with Regional Managers for all marketing and sales cost centres). Conclusions of estimates submitted to General manager and Marketing Services Manager for sanction.

Assist General Manager and Marketing Services Manager in the formulation of the Annual Marketing Plan and the 4-Year Divisional Plan.

Support General Manager (suggestions, guidance, recommendations) on marketing related matters to improve the effectiveness, profitability etc. of the Divisional operation.

Preparation, vetting and action planning of Policy Letters.

Analysis of products to determine which should be withdrawn.

Reporting recommendations to Commercial Manager, Inventory and Purchasing Committees.

Ensure high degree of discipline is maintained regarding accurate information and input for documentation.

\section{Duties and responsibilities - personnel}

Conduct interviews and select suitable employees (in conjunction with Personnel Department).

Evaluate (annually) performance of reporting personnel. Support, guide and evaluate training needs in preparation for possible promotion and increased responsibilities (possibly in accordance with succession plan).

Propose to General Manager recommendations in salary levels for all personnel reporting directly, based on performance assessment.

Offer guidance and suggestions to improve field personnel skills and their overall performance as and when required.

Ensure minimal personnel turnover. 


\section{The oll company's job description}

\section{The Marketing Manager}

Position in the Organisation: Reports directly to the General Manager and to the Managing Director.

The Marketing Manager's colleagues are all those managers located on the same organizational level as himself, i.e. the managers for Refining and Exploration; Planning; Personnel; Corporate Affairs; Information Services; Administration and Finance. Since Marketing is central business function, there is a tendency to see the Marketing Manager as the most senior of the above managers; this is, in fact, not theoretically accurate.

Immediately answerable to the Marketing Manager are the heads of all sub-departments in marketing, i.e. managers of Agriculture and Consumer Sales; Retail Sales; Provincial Managers; Operations; Liquid Petroleum Gas; and Marketing Services.

Also answerable to the Marketing Manager are the Deputy Marketing Manager and the Marketing Manager's personal assistant.

\section{Purpose of the job:}

The Marketing Manager is accountable for all the marketing activities of the company in the Republic of South Africa and in adjoining territories. (Marketing activities include all sales activities in all categories of trade.)

Co-ordinates all activities of the Marketing Department.

\section{Areas of Activity}

\section{Planning}

Major departmental planning is undertaken on a three-year basis in order to formulate long-term strategies.

Planning is also undertaken annually in order to specify short-term strategies and the marketing budget for the forthcoming year.

In order to assess what future market trends and behaviour will be for a forthcoming year, the Marketing Manager obtains relevant information, forecasts and recommendations from relevant sub-departments.

With the assistance of someone like the Marketing Services Manager, the Marketing Manager then draws up an hypothesis for the following year. Market growth in the various sectors will, for example, be estimated. Broad marketing strategies and objectives for the entire department will then be set in accordance with expected future developments.

Annual and triennial plans are flexible, and may be modified should this prove necessary.

\section{Controlling and Monitoring of Interdepartmental Activities}

Sees each manager once a week on a formal basis in order to discuss relevant developments within respective subdepartments. Managers also submit reports once a month to the Marketing Manager, highlighting and accounting for any exceptional performance (whether good or bad) within their departments.

If a critical issue should arise at any time in an area, the relevant manager is expected to inform the Marketing Manager immediately, without waiting for the scheduled weekly meeting.

On a day to day basis, the relationship between the Marketing Manager and interdepartmental managers is an informal one. The Marketing Manager upholds an 'open door' policy, and may be approached for advice or assistance whenever he/she is available.

The Marketing Manager also controls all matters pertaining to real estate and leasing; decisions in this area, must, however, be approved of by the Board.

\section{Co-ordination of Marketing Activities}

Holds a monthly marketing management committee meeting. The purpose of this meeting is for the mutual exchange of relevant information, the discussion of any problem areas, current and future developments, the thrashing out of policies...

Certain matters such as the company's advertising programme, and competitors' strategies will be discussed by the Marketing Manager with the Executive Management Committee.

\section{Contact with Outsiders}

This would include the following types of people:

- people from other departments seeking advice, or needing to consult with the Marketing Manager on a corporate issue;

- customers seeking advice;

- external public relations activities, such as attending certain business functions, opening new centres, addressing academic and business institutions and women's groups, contact with the media ....

As much as $60 \%$ of the Marketing Manager's time can be spent with people outside of the marketing department.

\section{Degree of Supervision received and given}

No supervision as such is given to the Marketing Manager. $\mathrm{He} /$ she is accountable to the General Manager and Managing Director, in that they assess the results of the department.

Supervision given to subordinates has been specified under 'Areas of Activity'.

\section{Pressure of Work}

Ensures that departmental deadlines are met, such as deadlines for budgets and specific reports.

The enormous scope of this position and its manifold activities naturally make for demanding work. The successful Marketing Manager has to have, above all, an excellent ability for effective time-management, and the discrimination between what requires immediate or secondary attention.

\section{Consequence of Error}

Consequence of error is one of nine factors taken into account in the job evaluation system. Each of the nine work related factors is rated according to its importance or severity for a specific job on a scale graded in intervals from $1-17$.

For the Marketing Manager, the consequence of error is stated at $\pm 11-14$. Errors committed by the Marketing Manager are considered to have far-reaching effects on money, materials, manpower and company prestige. The cost of an error could well run into millions. In fact, errors 
at this level could possibly not only affect the company itself, but the entire oil industry, and, at worst, the national economy.

Since it is the Marketing Manager's duty to closely monitor the soundness and accuracy of subordinates work, he assumes entire responsibility for any errors committed within the marketing department.

\section{Working Conditions}

OVERTIME is a regular component of the job. This is due to the tremendous scope of activities and unavoidable interruptions inherent in the job.

TRAVEL is extensive (throughout Southern Africa) and very frequent. As many as two days in one week could entail travel outside of Johannesburg.

\section{Education}

The ideal educational background should entail a broad business background, with a degree preferably in subjects like economics, accounts, and perhaps some marketing. Marketing knowledge can, however, be acquired on the job, and a formal training in this discipline is not imperative. Some formal management training is imperative.

\section{Experience}

At least fifteen to twenty years' work experience is essential for this job, and of this, at least five to six years should be in the oil industry.

The type of candidate likely to be chosen for this position would be someone like a provincial manager or the Deputy Marketing Manager.

\section{Linguistic Requirements}

Bilingualism is essential. The incumbent should be fairly articulate.

\section{The drug manufacturer's job description \\ Job title: Director of Marketing \\ Division: Marketing \\ Job summary}

Responsible for: Contributing to the growth and profitability of the Company.

Ensuring continued profitable selling of all Company products through effective management of the marketing process.

Ensuring continued satisfaction of the identified needs of all customers utilizing the Company's range of products.

Concentrating marketing activities in the Republic of South Africa, Swaziland, Lesotho, Botswana and the independent states within South Africa, as well as selected African countries.

Planning, organizing, leading and controlling the major specialized activities performed in the marketing process.

\section{Major functions \\ Planning}

Develops and maintains a recognized system of planning which is understood, accepted and used by all sales/marketing personnel.

\section{Organization Performance}

Arranges and relates all marketing activities to ensure most effective performance and co-ordination of efforts.

\section{Leading Performance}

Establishes and maintains a working environment characterized by:

- high motivation

- effective action

- optimal utilization of personnel capabilities

- acceptance and the need to attain objectives and conform to standards

\section{Controlling Performance}

Develops and implements controls in order to assess and regulate completed work and work in progress in terms of objectives and plans.

\section{Sales Performance}

Builds and maintains sound business relationships with all customers and achieves at least budgeted sales in units and Rands.

\section{Export Performance}

Attains budgeted export sales annually and to identify and develop new opportunities in export territories.

\section{Marketing Performance}

Provides support to the domestic and export sales divisions, identifies and explores new product and profit opportunities and ensures optimal realization of existing potential and opportunities.

\section{Tenders and Pricing}

Ensures that all tenders for the Company's range of products are responded to according to laid down standards. Develops and maintains a rational pricing policy and price determination procedures derived from a consideration of cost, customers and competitive situation.

\section{Advertising and Promotion}

Supports the selling effort by promoting the Company image, building and maintaining sound business relationships with key customers and by demand-creation through effective advertising.

\section{Distribution}

Establishes and maintains an efficient Distribution and Customer-Services Department in accordance with the laid down standards.

\section{Functional activities}

Ensures that each manager develops and uses monthly and annual objectives to ensure predetermination of courses of action.

Ensures that each manager is involved continuously in the estimation and prediction of future trends and operating environments based on analytical projections.

Ensures that each manager prepares and implements programmes, schedules and budgets for all marketing activities. 
Establishes policies and procedures to facilitate the action involved in answering repetitive questions, problems and specified work.

Develops an effective organizational structure based on the identification and grouping of activities to be performed.

Adapts this flexible organizations structure as necessary as the enterprise continues to develop.

Undertakes to assign duties and responsibilities in terms of activities to be undertaken and missions to be fulfilled. Ensures a clear understanding and acceptance of assigned responsibilities and the implied obligation to fulfil these duties exists by granting responsibility and commensurate authority in writing.

Facilitates the creation of a climate conducive to the establishment of sound and consistent relationships which would result in mutually co-operative efforts by ensuring a clear understanding and acceptance of departmentation, rights obligations and authority.

Implements an organized decision-making process to ensure logical conclusions and judgements. Applies this technique in such a way that problems are avoided.

Establishes a two-way communication system to create understanding among people at all levels.

Establishes high motivation by striving to integrate the needs of the people with the welfare of the company, thus ensuring a good balance between individual motivation and co-operative efficiency.

Recruits and selects people capable of performing their assigned duties and willing to accept the obligation to work towards the attainment of Company goals.

Provides each individual with the opportunity to maximize aptitudes, abilities and needs, thus improving the knowledge, attitudes and skills of people through continuing education and training.

Establishes criteria to measure and evaluate methods and results. Performance measurement will be based on information gained from a system involving records, observation and prompt, regular, concise and precise reports.

Rectifies adverse deviation from desired performance levels and ensures improvement.

Ensures that sales performance meets required standards set out in budgets of units and Rands, for each range of products.

Ensures that customers consistently rate the Company highly on the quality of representation.

Evaluates export performance by comparing with budgeted sales per territory per month.

Develops new opportunities in existing and new export countries.

Identifies new product opportunities; plans and implements new product launches.

Prepares marketing plans as scheduled.

Prepares a twelve-month rolling forecast on a quarterly basis, and reviews this on an exception basis every month.

Prepares annual sales and expense budgets.

Co-ordinates or initiates product changes and tests customer response.

Gathers, classifies, records, analyses and disseminates relevant market and product related information.

Ensures that all relevant publications for tenders are scanned and obtains copies of tender documents prior to due date.

Prepares and submits tenders after careful study and preparation and initiates follow-up procedures.

Maintains accurate and up-to-date product cost records, competitive price information, including tenders and ensures strict adherence to price determination procedures.

Plans, manages and executes effective advertising campaigns with due regard to budget preparation, timing (product phases), copy planning and preparation, media selection and evaluation of effectiveness.

Plans and organizes participation in medical congresses and special national symposia relating to the Company's field of endeavour.

Organizes plant tours for key customers.

Establishes sound relationships with homelands, technikons and universities.

Establishes and maintains effective inventory control of finished goods.

Ensures prompt and accurate order processing and billing, efficient warehousing and transportation at the lowest possible cost consistent with good service.

Ensures efficient customer service by ensuring the right product is in the right place at the right time and in the right amounts.

\section{A paper product's job description}

Position: Marketing Manager, Personal Care

Organization Unit: Marketing Division - Consumer Business

Reports to: Marketing Director

Subordinates: Three Product Managers

Position Purpose: To effectively manage and develop the Feminine Hygiene, Infant Care and Non-Woven Fabric Products so as to ensure achievement of short and long term volume and operating profit return on asset growth objectives.

\section{Nature and Scope}

Initiate, develop and control short and long range marketing strategies utilizing leadership and organizational skills.

Supervise and ensure the development and implementation of individual product line marketing strategies and plans in order to achieve the resultant short and long term volume and operating profit objectives.

Motivation and development of Product Management personnel and their subordinates.

- Conduct half-yearly formal reviews of individual progress.

- Recommend annual salary plan and changes to the plans resulting from changes in performance.

- Recommend internal and external training and development programmes.

Controls budgets for the various product lines. Gives final approval of consumer research, consumer promotion and pack designs and is responsible for the initial approval of product specification changes and advertising campaigns.

Recommends list price and discount adjustments and approves the monthly sales forecast updates. 
Ensures proper co-ordination and communication of marketing activity for the product lines to the Sales, Operations and Finance Divisions.

Works closely with Marketing Services Assistant to ensure that meaningful analyses of consumer and trade research is undertaken and corrective action implemented.

Ensures that his subordinates are kept informed on pertinent data emanating from sources such as the company's subsidiaries as well as the world Consumer Business Group Steering Committees on Feminine Hygiene, Infant Care and Non-Woven Fabrics.

Ensure that he is up-to-date with trade developments, changing consumer needs and technical developments with regard to markets within which his group operates.

\section{The chain store's job description}

\section{Key Objective/Purpose}

Leads the marketing function in the chain, which contributes significantly to sales and profits and embraces strategic and tactical marketing planning, advertising, sales and merchandise promotion, display, packaging and market research and ensures the presentation of a coherent and consistent identity to the customer.

\section{Relationships}

\section{Incumbent reports to the Group Director.}

Reporting to the incumbent are:

- Advertising Manager

- Sales Promotion Manager

- Merchandise Promotion Manager

- Display Manager

- Creative Manager

- Secretary

\section{Internal relationships:}

The incumbent is a member of the Chain Management Committee, the Chain Merchandise Committee and the Group Marketing Committee. Contributes to the strategy decisions affecting all divisions of the chain and those on inter-chain issues of a marketing nature.

\section{External Relationships}

Liases with advertising and direct response marketing agencies, packaging consultants and professional or semiprofessional organizations in the marketing field. Deals with representatives of other companies, retailers and specialist firms.

\section{Nature and scope of job}

Ensures that the chain's intended market positioning is projected coherently and consistently to the diverse elements of a wide ranging target market, in an extensive variety of different media and activities and at the same time to maintain very high levels of cost effectiveness.

Under his direct cuntrol fall: campaign planning, advertising, sales promotions, display and merchandise presentation.

Directs, motivates and controls highly skilled and experienced experts within his division and in the advertising, direct response marketing and packaging agencies.
Influences merchandise assortments, store design, operation and credit areas.

Contributes to formulation of chain's strategy through five-year plans and defines and communicates marketing policy - set objectives, directs preparation and reviews them to ensure that they are met and that financial resources are effectively allocated.

Reviews promotions, evaluates results, ensures all activities meet objectives and express chain's image in the most cost-effective way.

Identifies marketing problems and opportunities, works toward their solution or exploitation. Briefs research projects, evaluates and interprets them, communicates their results within the chain.

Provides a productive working environment, motivation and direction to his staff for the improvement of the business. Keeps abreast of market conditions and developments, latest techniques and evaluates them for potential use.

Ensures availability of resources, skills and services needed to ensure high standards, seeks to extend range of skills of his staff members.

Requirements: (Ideally)

A thorough understanding of strategic and tactical marketing principles and practices obtained through professional training and extensive experience.

Human relations skills are also very important.

\section{Degree of Authority}

Members of Chain Management Committee which reviews policies, actions, proposals and results of chain.

Group Director approves marketing policies and seasonal campaigns and budgets.

Individual promotions approved by incumbent except where they depart significantly from plans.

Selects all suppliers other than the advertising agency (the change of which requires Managing Director's approval.)

Approves annual budget of approximately $\mathbf{R} \times$ but must obtain permission from superior to exceed it by any amount more than $\mathrm{R}$ y. Recommends appointment, dismissal and remuneration of the five senior people reporting to him. Has authority to make changes himself with less senior positions.

\section{Conclusions}

Two things are clear from this pilot study.

There is no standard Marketing Job. The marketing tasks vary from industry to industry as well as the role of marketing within those industries. The main purpose of the job in the tool manufacturer was 'to meet/exceed the Metal working Products Division annual sales budget, whilst maintaining the level of administration and service costs within the sales trend, so that the nett operating result can be obtained.'

The Oil Company's job description states that the marketing manager's main purpose is to be 'accountable for all the marketing activities of the company in the Republic of South Africa and in adjoining territories.' The Paper Products manufacturer's marketing director's main 
purpose is 'to develop strategies, short and long term plans to maximize the volume and profit growth of the Consumer Business Division. To organize, manage and control the Consumer Business, Marketing Division, in order that profit objectives are reached.' The key purpose of the chain store marketing manager, is said to be 'leads the marketing function in the chain, which contributes significantly to sales and profits and embraces strategic and tactical market planning, advertising, sales and merchandising, promotion, display, packaging and market research and ensures the presentation of a coherent and consistent identity to the customer.' The drug manufacturer's job description does not state the main purpose of the job but rather lists some responsibilities.

It is clear from these statements that the job of marketing director/manager does not have a unified purpose. This is sometimes contrary to marketing definitions and the tasks of marketing as described in the literature.

There is no standard format for writing job descriptions, nor do the job descriptions conform in every way to job description theory. Only one of the five job descriptions mentions work conditions for the employee as well as to specify the performance expected of the employee. The oil company clearly states in its job description that the marketing manager will have to work overtime and travel extensively. It states that 'the successful marketing manager has to have, above all, an excellent ability for effective time management, and the discrimination between what requires immediate or secondary attention.'

Thus only one of the job descriptions studied, that of the oil company, conforms to most of the functions of a job description. It is an honest document. It does not only 'sell' the bright side of the job to the candidate. It helps the applicant as a self-evaluating check-list to help him gauge his competence not only to handle the work called for but also the working conditions and performance expected of him. These are critical factors. A person may be able to plan, organize lead or control a marketing department. But only a few people may be able to perform those activities while working eighteen hours a day, seven days a week and spend three days a week away from home.
It should be clear from this pilot investigation that marketing job descriptions have limitations in practice. However, job descriptions perform valuable functions. They should not be done away with.

Both marketing and personnel management should be aware of these limitations. The job of marketing manager could be different between industries as well as within individual firms in one industry. The tasks that a person will have to perform within a particular company may differ from the tasks he/she has performed as a marketing manager previously. Thus, it is recommended that the marketing job description should be drawn up with care by top management as well as personnel management in such a way so that it reflects as an honest, accurate document that top management, personnel and the marketing manager understand and interpret in the same way.

Unfortunately a suggested normative 'perfect' job description does not exist. This will depend on the type of industry, the type of company within that industry, the organizational structure, the systems within the company, the marketing orientation of the company and the personal preferences of the chief executive.

\section{References}

1. Orpen, C. The Principles of Personnel Psychology, Juta \& Co. Lid., 1979, p. 5.

2. See amongst others: Beatty, R.W. et al. Personnel Administration London: Addison-Wesley, 1977, p.55-61. Armstrong, M, Personnel Management Practice, London: Kagan Page, 1977, p.90-91. Schreier, C.E. et al., Personnel Administration Today: Readings and Commentary, London: Addison-Wesley, 1978, p.86-92; and Walker, J., Human Resource Planning, New York: McGraw-Hill, 1980 p. 295 .

3. Klinger, D E., 'When the Traditional Job Description is Not Enough,' in Personnel $J$., April, 1979, p.244.

4. See amongst others: Kotler, P., Marketing Management, Analysis Planning and Control, 4th ed., New Jersey: Prentice-Hall, 1980 p. $18-37$.

McCarthy, E.J., Basic Marketing, 7th ed., Richard D. Irwin, Homewood, 1981, p.29-53.

Davis K.R., Marketing Management, 4th ed., New York: John Wiley \& Sons, 1981, p.1-36.

Evans, J.R., et al., Marketing, MacMillan, 1982, p.16-19

5. The author wishes to acknowledge the help given to him by the executives of the five companies who prefer to remain anonymous. 